解 説

\title{
放電プラズマ焼結技術を用いた熱電変換材料開発
}

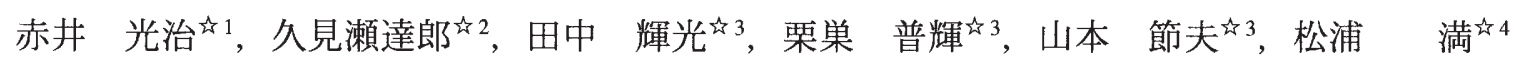 \\ ஷ1山口大学メディア基盤センター，７55-8611 宇部市常盤台 2-16-1.

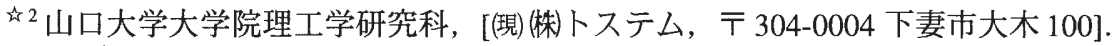 \\ 出 3 山口大学大学院理工学研究科, $\overline{7} 755-8611$ 宇部市常盤台 2-16-1. \\ ${ }^{4} 4$ 山口大学工学部, [玨) 放送大学山口学習センター, = 756-0884 山陽小野田市大学通 1-1-1].
}

\section{Development of Thermoelectric Materials Fabricated by Spark Plasma Sintering Methods}

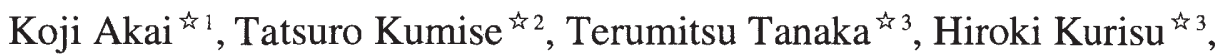 \\ Setsuo Yamamoto ${ }^{\text {is } 3}$ and Mitsuru Matsuura ${ }^{\text {is } 4}$ \\ is 1 Media and Information Technology Center, Yamaguchi University, 2-16-1 Tokiwadai, Ube 755-8611, Japan. \\ ${ }^{2}{ }^{2}$ Graduate School of Science and Technology, [Present Address: Tostem Corp., 100 Ohgi, Simotuma 304-0004, Japan]. \\ ${ }^{45}$ Graduate School of Science and Technology, Yamaguch University, 2-16-1 Tokiwadai, Ube 755-8611, Japan. \\ ${ }^{2}{ }^{4}$ Yamaguchi University, [Present Address: Yamaguchi Study Center, The Air of The University, 1-1-1 Daigaku-dori, Sanyo-Onoda 756-0884, Japan].
}

Received April 13, 2007

\section{SYNOPSIS}

We study the thermoelectric properties of some candidates of high performance thermoelectric materials that are fabricated by the spark plasma sintering technique. The first topic is concerned with preparation of higher density samples of zinc antimony compound $\mathrm{Zn}_{4} \mathrm{Sb}_{3}$ for which it is known that fabrication of high density samples is a key point to improve the thermoelectric performance. The second topic is concerned with reducing of grain sizes of sintered samples to decrease the thermal conductivity. The third topic is concerned with the new approach combining the experiment and the theory for magnesium silicide $\mathrm{Mg}_{2} \mathrm{Si}$. It is one of a good thermoelectric material with the simple crystal structure. Therefore the material is the appropriate material as a test bed of the theoretical method based on the ab-initio electronic structure method.

\section{KEY WORDS}

thermoelectric material, spark plasma sintering, first principle electronic structure calculation, $\mathrm{Zn}_{4} \mathrm{Sb}_{3}$, thermoelectric silicide

\section{1 緒言}

熱電変換材技術は熱エネルギーと電気エネルギーを相互に 直接変換する技術である.ペルチ工効果を用いた小型冷蔵庫 などはコンパクトで静かであることから既に実用化され普及 しつつある. また，情報化社会に欠かせないネットワーク機 器や CPUに対する高精度な冷却用途などでも期待されてい る. 更に, 冷却以外でも幅広い用途で注目されており, 発電 所や工場などで無駄に捨てられている熱を利用する廃熱回収 を目的とした発電や, 高感度・コンパクトな熱センサーなど でも興味が持たれている.エネルギー問題への感心が高まる 中で, 最近注目されてきたのが自動車廃熱利用への応用であ る. 自動車は世界に普及しているが, 実際に動力として利用 されているのは20〜30\%程度であり，多くは廃熱として無 駄に消費されている. 自動車廃熱利用では, 熱電システムと して機能することが要求され, 熱交換, 接合など様々な視点
}

から研究が必要となる ${ }^{1}$. 最近の自動車への取り組みについ ては, 松原等による解説で詳しく紹介されているので参考に されたい2). 以上のように幅広い用途があるにも関わらず, 実 際には熱電変換技術は限られた用途で利用されるのに留まっ ている.これに対する重要な課題が, エネルギー変換効率の 高い材料の開発である.

熱電変換材料の特性は性能指数 $Z$ もしくは絶対温度 $T$ をか けて無次元化した性能指数ZTにより特徵づけられる. エネル ギー変換効率は理論的なエネルギー変換効率の上限である Carnot 効率と $Z T$ を用いて表現され， $Z T$ の増加と共に単調に 増大する. Fig.1に幾つかの高性能熱電材料の性能指数を示し た. $Z T>1$ がデバイス化可能な 1 つの目安とされており，BiTe 系材料などがデバイスとして実用化されている.しかし, 自動車に搭載するなど一般に普及するためには ZT 2 が最低 限必要との話もあり, 幅広い温度領域に対して更なる高性能 


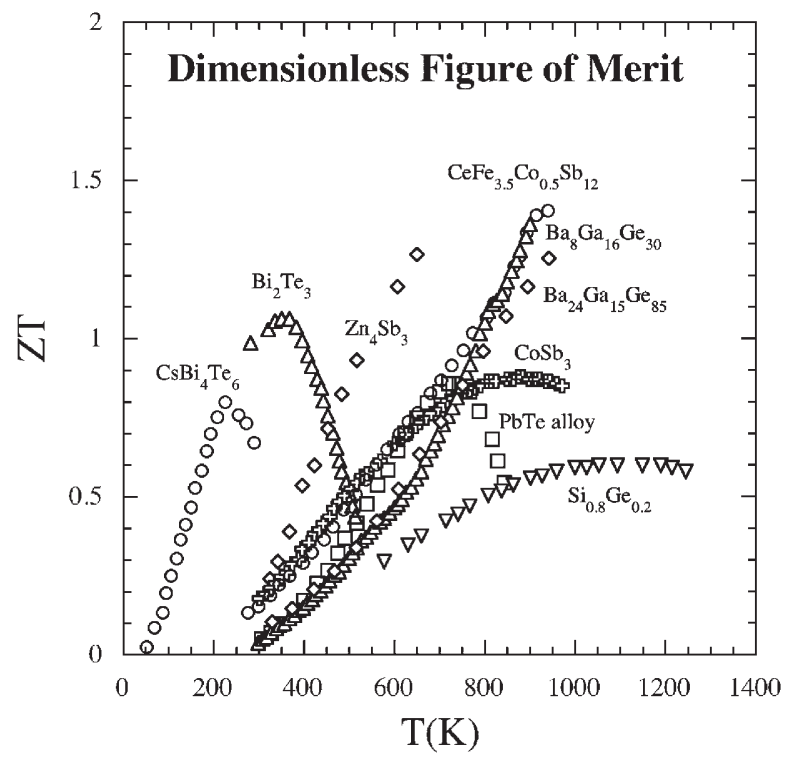

Fig.1 Dimensionless figure of merit for several high performance thermoelectric materials.

化が求められている.

無次元性能指数 $Z T$ は $T S^{2} \sigma / \kappa(\mathrm{S}$ : 熱電能, $\sigma$ : 電気伝導度, $\kappa$ : 熱伝導度)により表されるため, 高性能熱電変換材料では 「ガラスのように熱伝導度が低く, 結晶のように電気を流す (Phonon Glass and Electron Crystal: PGEC)」 ${ }^{3)}$ が高効率材料開 発の指針となっている. しかし，一般に電気伝導度の高い物 質は熱伝導度も高く, 熱伝導度だけを低減することは困難で ある.このため, 単純な物質での高性能化は難しく, 組成制 御や構造制御等により電子構造およびフォノン構造を制御す ることが必要とされる.このため我々は実験的手法による材 料探索と共に，第一原理計算手法を用いた特性評価を行い， 理論と実験の両面から高効率熱電材料の設計を進めて来た.

実験的なアプローチでは高性能化において適切な試料作製 法を選択することが重要である. 材料合成プロセスとしては 固相反応法や溶融法などいくつかの手法がある. 熱電変換材 料の開発では熱応力や機械強度, 接合のマッチングなどデバ イス応用を視野に入れているため, 焼結体を用いた研究が主 流である。我々のグループでは焼結法として Spark Plasma Sintering (SPS) を用いて来た. SPS 法のメリットは, (1) 1000 ${ }^{\circ} \mathrm{C}$ を超える高融点材料でも用いることができること，(2)一 様な焼結体が作り易いこと, (3)短時間のプロセスであるので 粒径の肥大化抑制が可能であること，が上げられる．以下の 章では,このようなメリットを持つSPS 法による試料作製と 作製された焼結体の特性, 熱電特性の高性能化, 計算による 解析について，これまでの取り組みの結果を述べる.

\section{$2 \mathrm{Zn}_{4} \mathrm{Sb}_{3}$}

$\mathrm{Zn}-\mathrm{Sb}$ 系材料は $\mathrm{ZnSb}, \mathrm{Zn}_{4} \mathrm{Sb}_{3}, \mathrm{Zn}_{3} \mathrm{Sb}_{2}$ など複数の組成を持つ ことが知られている. 熱電変換材料としては, ZnSbおよび
$\mathrm{Zn}_{4} \mathrm{Sb}_{3}$ が主に研究されている. $\mathrm{ZnSb}$ は電子特性が優れてお り, 機械強度も高いなどメリットを持つが, 構造が比較的単 純であるため熱伝導度が比較的高く, 熱伀導度の低減が大き な課題である. 一方, $\mathrm{Zn}_{4} \mathrm{Sb}_{3}$ は熱伝導度が $1 \mathrm{~W} / \mathrm{mK}$ 以下と大 変低いのが特徵である. $\mathrm{Zn}_{4} \mathrm{Sb}_{3}$ には低温での $\alpha$ 相 $(\sim 263 \mathrm{~K}$ ) と室温以上で安定に存在する $\beta$ 相 $(263 \mathrm{~K} \sim 765 \mathrm{~K})$, 更に高温 での $\gamma$ 相 $(765 \mathrm{~K} \sim)$ の存在が知られている. 熱電材料として 注目されているのは $\boldsymbol{\beta}-\mathrm{Zn}_{4} \mathrm{Sb}_{3}$ である. $\boldsymbol{\beta}-\mathrm{Zn}_{4} \mathrm{Sb}_{3}$ は電子特性が $\mathrm{ZnSb}$ と同程度であり, 熱伝導度が低いため, $\mathrm{ZnSb}$ の欠点を 補う材料として注目される ${ }^{4}$. しかし, ZnSbに較べ脆くクラッ クが入り易いことが素子化において大きな問題となっていた. 大空らはこれに対し, ホットプレス焼結法を用い高密度 $\beta$ $\mathrm{Zn}_{4} \mathrm{Sb}_{3}$ を作成することにより, 更なる高性能化および強度の 弱点を克服した ${ }^{5)}$.

大空らの作製した $\beta-\mathrm{Zn}_{4} \mathrm{Sb}_{3}$ はMayerらにより報告されてい た結晶構造( ${ }^{6}$ で計算される理論密度を超える高い密度值を持 つ. これについて, 最近 Snyder等はSOR光を用いたX線解析 とMaximum Entropy法を組み合わせた構造解析および電荷分 布の解析から, 新たな高密度構造を提案している ${ }^{7,8)}$. これに よれば, Znはいくつかの占有サイトを持ちMayer等の結晶モデ ル以上に Znの充填が可能なこと, 複数の占有サイトに $\mathrm{Zn}$ が ランダムに入ることによりアモルファス的な不規則性を持ち, 熱伝導率が非常に小さくなっていることが結論づけられている.

我々は数時間の焼結過程を要するホットプレス法を用いず, より簡便で一様な焼結体が作製できるSPS法と室温で粉体の 加圧成形: Room Temperature Molding (RTM) を組み合わせる ことにより $\beta-\mathrm{Zn}_{4} \mathrm{Sb}_{3}$ の高密度化, 高性能化を行った ${ }^{9,10)}$.

\section{1 実験手法}

$\beta-\mathrm{Zn}_{4} \mathrm{Sb}_{3}$ の作成は, $\mathrm{Zn}$ (純度 99.99\%) と $\mathrm{Sb}$ (純度 $99.999 \%$ ) の原料を化学量論組成 $\mathrm{Zn}: \mathrm{Sb}=4: 3$ から Zn 量を $2 \mathrm{at} \%$ リッチに して混合し, 真空封じ込め装置により 4 時間, $623 \mathrm{~K}$ の温度で 固相反応を行った. 生成試料をジルコニア製ボール(直径: 1.0 $\mathrm{mm}$ と $4.0 \mathrm{~mm}$ の両方) を用いたボールミル $(\operatorname{Ar}$ 雾囲気, 4 時間) で粉砕後, ふるいを用いて粒径 $106 \mu \mathrm{m}$ 以下の粉末を得た. 得 られた粉末を室温整形(RTM)し，SPSにより焼結体を得た. Fig.2 に RTM 法の概略図を示す. SPS 用のグラファイトパン 于 $(\phi=20 \mathrm{~mm})$ およびグラファイトダイの中心部に室温加圧成 形を行った圧粉体 $(\phi=15 \mathrm{~mm})$ を置き, 周りの隙間に $\beta-\mathrm{Zn}_{4} \mathrm{Sb}_{3}$ の粉末を敷き詰めた. 圧粉体は $170 \mathrm{MPa}$ で加圧した. SPS の 条件は焼結温度 $753 \mathrm{~K}$, 保持時間 15 分, 圧力 $25 \mathrm{MPa}$ とした。

物性評価サンプルはSPS後に得られた試料から中心部を切 り出し, 評価用に加工した。試料密度測定にはアルキメデス 法を用いた. 結晶構造は粉末 $\mathrm{X}$ 線装置 $(\mathrm{Cu}-\mathrm{K} \alpha)$ を用いて測定 した. また, 試料表面を鏡面研磨後, ケミカルエッチングし, 表面組織を電界走査型電子顕微境 (SEM) で観察した. 熱電能 および電気伝導度は直流 4 端子法により测定した。また, 熱 伝導度はレーザーフラッシュ法により測定した。

2.2 結果と考察

Table 1 にサンプル密度について RTM有りと無しの比較お 


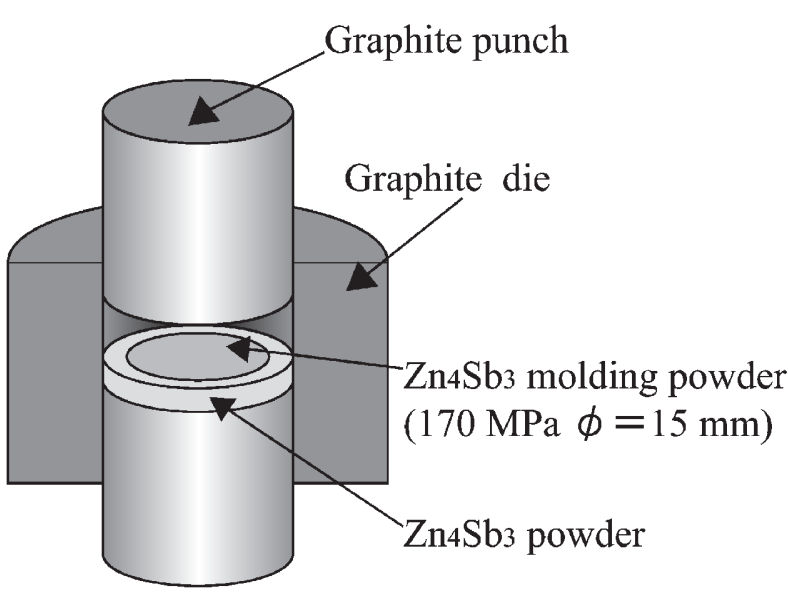

Fig.2 Room temperature molding method with SPS.

Table 1 Sintering temperature dependence to bulk densities.

\begin{tabular}{lc}
\hline & Density $\left(\mathrm{g} / \mathrm{cm}^{3}\right)$ \\
\hline SPS743 K & 6.11 \\
RTM+SPS733 K & 6.56 \\
RTM+SPS743 K & 6.53 \\
RTM+SPS753 K & 6.27 \\
\hline
\end{tabular}

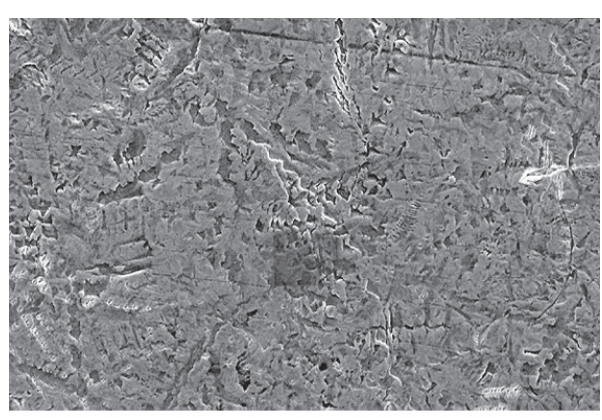

Without the RTM method $\overline{1 \mu \mathrm{m}}$

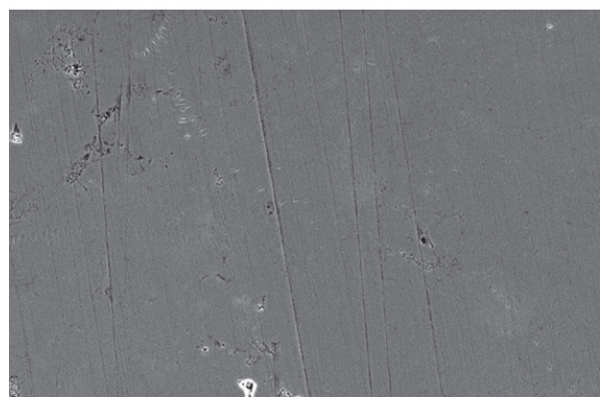

With the RTM method

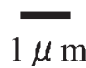

Fig.3 SEM images of the compacts sintered without the RTM method and with the RTM method

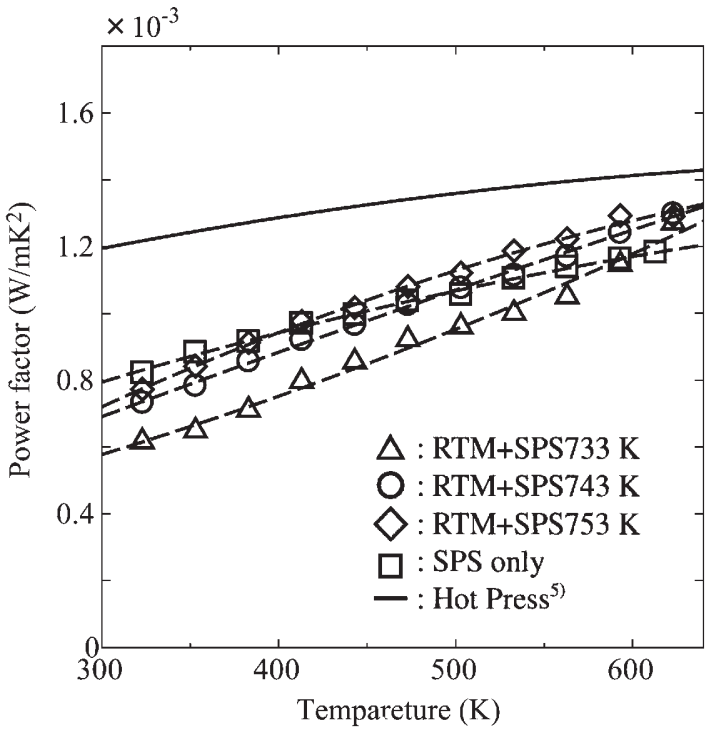

Fig.4 Power factor as a function of temperature.

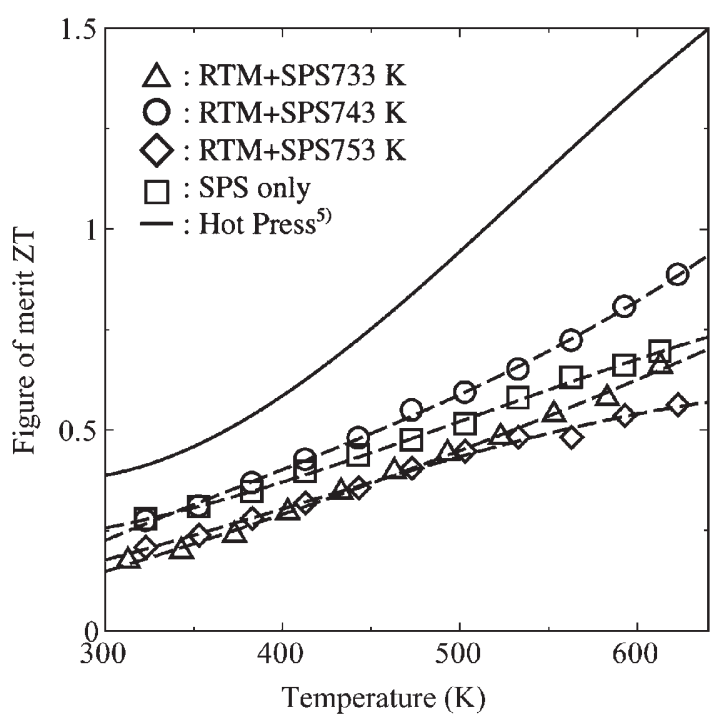

Fig.5 ZT as a function of temperatures.

よびSPSにおける焼結温度の依存性を示す. 同じ焼結温度で 比較するとRTMを行うことにより 7\%の密度の増加が見られ ており，RTMが高密度化に有効であることが示されている. 焼結温度については温度の上昇とともに密度の低下が見られ る. Fig.3にSEMによるRTM有りと無しの表面組織の違いを 示す.図で示されるようにRTMを行うことにより緻密で一様 な組織構造を持つ試料が作製できていることが分かる.これ から, 密度に見られる違いはRTMにより空隙が減少したこと が原因であると結論される.一方, XRDによる結晶構造解析 では焼結温度に依存せずRTM 試料でほぼ単相であること, RTM無しではRTM有りに比べわずかであるがZnSb相を示す パターンが多く見られること，を確認している。

Fig.4およびFig.5はそれぞれ, 出力因子 $\left(\mathrm{PF}=S^{2} \sigma\right)$ および無 次元性能指数 ZTの温度依存性を示す. Fig.4ではRTM有り・ 
無しで電子特性に大きな違いは見られない。しかし，温度依 存性に若干の違いが現れている. RTM有りの焼結温度依存性 については, 出力因子が焼結温度の増加と共に増大する傾向 が見られている. Hot Press法により作成された試料5) と比較 すると, SPS 法の方が出力因子は小さく, 低温で違いがより 顕著になっている.この違いは主に熱電能の値の違いによる 結果である. ただし，熱電能の值の違いに加え，出力因子の 温度依存性にも違いが見られることから, キャリアー濃度の 違いに加えZn組成等の違いに起因して電子構造が異なってい る可能性も示唆される.

Fig.5 から出力因子同様に性能指数についても RTMによる 大きな違いは見られていない。一方, 焼結温度依存性について はZTの值に若干のばらつきが見られることに加え, 温度変化 の傾向に違いが見られる.この違いは熱伝導度の違いにより 生じている.出力因子で最適であったRTM+SPS 753Kでは熱 伝導度が $1.2 \mathrm{~W} / \mathrm{mK}$ を超えており ZTでは相対的に低い結果に なっている. SPS 試料で最も高い ZT を示す RTM+SPS 743K では熱伝導度が $0.9 \mathrm{~W} / \mathrm{mK}$ 程度で最も低く, ほとんど温度依存 性を持たない。この場合のZTはHot Press法の結果にはおよば ないが $623 \mathrm{~K}$ において $Z T=0.9$ とほぼ 1 に近い值が得られた.

室温加圧成形とSPSの組み合わせにより, 高密度化が行え ることが分かった，一方，熱電特性に対し極端な違いは現れ ないが, $550 \mathrm{~K}$ 程度以上の温度で性能指数の増大が見られた。 これにより ZTが 1 程度の性能を持ち, SPS 法による作製手法 の有効性が示された.

\section{3 高マンガンシリサイド $\mathrm{MnSi}_{\mathrm{x}}$}

近年, 材料開発において, 環境負荷物質を別の物質や元素 に置き換えることが求められると共に, 新規材料開発におい ては環境負荷物質を使わないことが重要となっている.この ため, 環境への負荷が小さく, 豊富に存在するシリサイド化 合物は熱電材料開発でも興味が持たれている.

$\mathrm{Mn}-\mathrm{Si}$ 系材料は $800 \mathrm{~K}$ 程度の中高温領域で性能が高く, 軽 量であることから自動車廃熱利用など可搬性が求められる用 途で期待される. Umemoto らはメカニカルアロイング(MA) と SPS 法を組み合わせ理論密度 $99 \%$ の材料を作製している 11). 彼らは $800 \mathrm{~K}$ 近くでZTが 0.6 から 0.7 程度の值を得ている. また, 小松製作所のグループは溶融材料にSPSを行うことに より理論密度 $98 \%$ 程度の試料を作製, $800 \mathrm{~K}$ で $Z T \sim 0.4$ を達 成した. 更にブリッジマン法を用いた単結晶試料では $700 \mathrm{~K}$ で ZT〜0.7 達成している ${ }^{22}$.

$\mathrm{Mn}-\mathrm{Si}$ 紊材料は $\mathrm{MnSi}_{x}$ と表示され, $x$ が1.67から 1.73 でい くつかの組成を持つ化合物が知られている ${ }^{13}$. これらの組成 で表される材料はNowotny Chimney Ladder (NCL)相と呼ばれ, $\mathrm{TiSi}_{2}$ 構造を基本構造とする長周期構造を持っている. 例え ば, $\mathrm{Mn}_{4} \mathrm{Si}_{7}\left(\mathrm{MnSi}_{1.75}\right), \mathrm{Mn}_{11} \mathrm{Si}_{19}\left(\mathrm{MnSi}_{1.727}\right), \mathrm{Mn}_{15} \mathrm{Si}_{26}\left(\mathrm{MnSi}_{1.733}\right.$ 等で ある. 興味深いことに, Mnサイトに長周期性はなく, $\mathrm{Si}$ サ イトのみが長周期構造を持っている. 熱電材料では, 半導体 にキャリアーを注入し, 最適なキャリアー濃度を実現するこ
とで高性能化を行うのが一般的である. $\mathrm{MnSi}_{x}$ を含む NCL 系 では価電子数 14 (VEC14) 則が知られており, Mnあたりの価 電子数が 14 の時に真性半導体となる. 例えば $\mathrm{Mn}_{4} \mathrm{Si}_{7}$ では $\mathrm{Mn}$ の価電子数は 7 であり, $\mathrm{Si}$ は 4 であるため, 価電子数は $(4 \times 7$ $+7 \times 4) / 4=14$ となり半導体となる. Fredricson 等は電子構造 計算から $\mathrm{TiSi}_{2}$ 構造を基本と考えることにより VEC14則が理 解できることを示した ${ }^{14}$. 既に示したようにVEC14則に従え ば $\mathrm{MnSi}_{x}$ 系では $x$ が 1.75 で半導体となり, 実際 $x=1.75$ 前後の 材料が高い熱電特性を示す.

我々は $\mathrm{MnSi}_{\mathrm{x}}$ 系において, 焼結体の粒径サイズ制御による 熱伝導度の低減を試みた.フォノンの波長程度の粒径では効 率的に音響フォノンが粒界に散乱され, 熱伝導度の低減が期 待される. SPS 法は他の焼結法に比べ短時間で焼結を行うこ とが可能であることから, 粒成長を押さえて焼結が可能であ り, 粒径の小さな焼結試料を作成できる特徵を持つ. SPS 前 に粉末の微細化を行い, 粉末サイズが熱電特性に及ぼす効果 を調べた ${ }^{15)}$.

\section{1 実験手法}

$\mathrm{Mn}$ (99.9\%) と $\mathrm{Si}(99.999 \%)$ の粉末を $\mathrm{Si}: \mathrm{Mn}=1: 1.85$ で秤量 し,アルミナ乳鉢を用いて更に粉砕, $250 \mu \mathrm{m}$ 以下の粉末を得 た. 得られた粉末を真空雾囲気, $1270 \mathrm{~K}, 5$ 時間, 固相反応 を行った. 固相反応後, $\mathrm{Mn}-\mathrm{Si}$ 粉末をボールミルで粉砕 (Milling) した. このとき, ステンレスボール $(\phi=3.2 \mathrm{~mm})$ およ びジルコニアボール $(\phi=1.5 \mathrm{~mm})$ を用いた. Milling の時間は 12 時間と 24 時間, 更に比較のため「行わない」の3 通りにし た. SPS は焼結温度 $1250 \mathrm{~K}$, 圧力 $55 \mathrm{MPa}$ ，保持時間 30 分の 条件で行った. SPS 後の焼結試料を特性測定用に加工後, 熱 電能, 電気伝導度, 熱伝導度を測定した. また, 焼結体の組 織観察のため破談面の SEM 観察を行った.

3.2 結果と考察

Fig.6に焼結試料のSEM 観察像および平均粒径を示す. Milling時間の増加と共に焼結試料の平均粒径が小さくなって いる. また, 密度がサイズの減少と共に小さくなることを確 認した.これにより, SPSの特性を生かした粒径制御が行え, 緻密な試料作製に成功した.

Table 2はレーザーフラッシュ法により測定した室温での熱 伝導度とMilling時間の関係を示す. 粒径サイズが減少するに つれ系統的な熱伝導度の低下が見られている. 粒径は $10 \mu \mathrm{m}$ オーダーであるが, サイズの減少がフオノン散乱の増大に寄 与していることが示唆される. Fig.7は $\mathrm{MnSi}_{x}$ の無次元性能指 数ZTの結果を示す.このとき, 熱電能および電気伝導度の温 度依存性は測定值を用いた。 また, 熱伝導度は室温の值で代 用した. Fig.7の結果から, 焼結体の粒径を微細化することに より性能指数が増大することが分かる. この場合, 熱伝導度 の低減効果と共に電気伝導度および熱電能の増大が見られて いる. SPS を活用した粒径制御は熱電特性向上に有効である ことが示された. しかし， $Z T \sim 0.3$ 程度に留まっており, 他 のグループの性能には達していない, 更なる熱伝導度の低減 が期待される. 


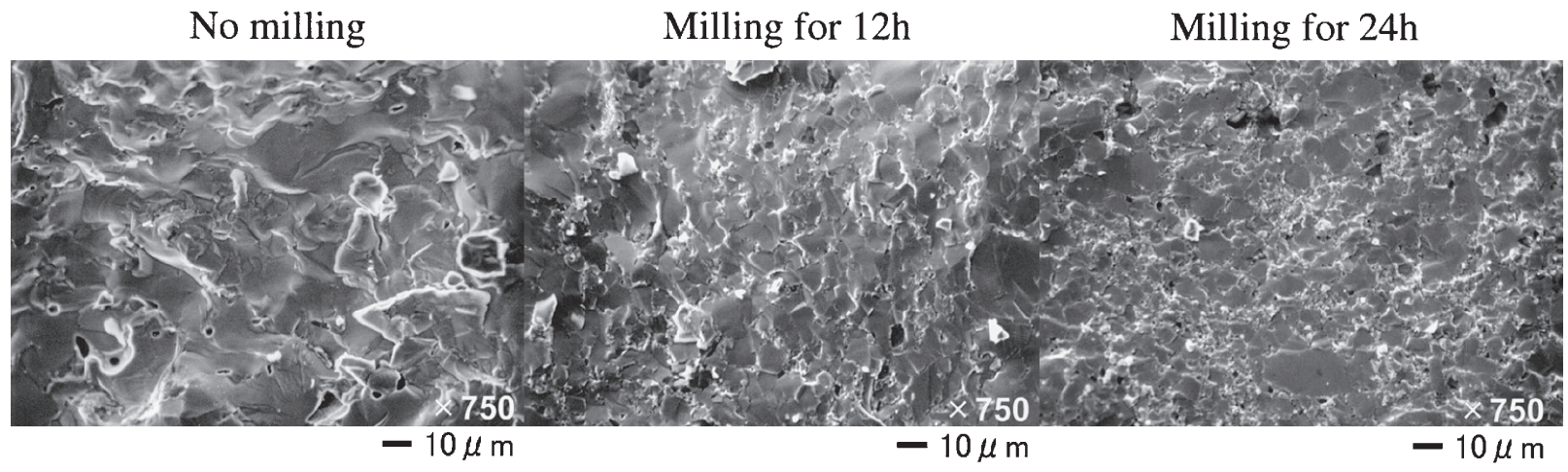

Average grain size: $71.1 \mu \mathrm{m}$
Average grain size: $19.2 \mu \mathrm{m}$
Average grain size: $13.6 \mu \mathrm{m}$

Fig.6 SEM images of $\mathrm{Si} / \mathrm{Mn}=1.85$ sintered samples.

Table 2 Milling time dependence for thermal conductivity at room temperature.

\begin{tabular}{|l|c|c|}
\hline & Milling time $(\mathrm{h})$ & $\begin{array}{c}\kappa @ 300 \mathrm{~K} \\
\left(\mathrm{~W} \cdot \mathrm{m}^{-1} \cdot \mathrm{K}^{-1}\right)\end{array}$ \\
\hline & No milling & 3.93 \\
\hline $\mathrm{Si} / \mathrm{Mn}=1.85$ & $12 \mathrm{~h}$ & 3.58 \\
\hline & $24 \mathrm{~h}$ & 3.35 \\
\hline
\end{tabular}

\section{$4 \mathrm{Mg}_{2} \mathrm{Si}$}

$\mathrm{Mg}_{2} \mathrm{Si}$ は 3 つの面心立方格子により構成される逆蛍石構造 を持ち，これまで述べた $\mathrm{Zn}_{4} \mathrm{Sb}_{3}$ や $\mathrm{MnSi}_{x}$ に比べると，遥かに 単純な結晶構造を持つ半導体である.この物質の半導体特性に ついては多くの研究がなされており, 電気伝導度の温度依存 性からバンドギャップは $0.66 \mathrm{eV} \sim 0.77 \mathrm{eV}$ との報告がある16). 電子構造計算についてもいくつかの手法により計算が行われ ている. 最近, Arnaud等はGW近似を用いた計算結果を示して おり，間接ギャップを構成する $\Gamma_{15 \mathrm{v}}->X_{1 \mathrm{c}}$ 間のエネルギ一差 は $0.65 \mathrm{eV}$ であり, 実験と整合する結果が提示されている ${ }^{17)}$.

高性能熱電材料の研究としては $\mathrm{Al} や \mathrm{Ag}, \mathrm{Sb}$ などの元素添 加が行われており，梶川等は $800 \mathrm{~K} て ゙ Z T 〜 0.67$ を達成してい る ${ }^{11,18)}$ ，結晶構造が単純であることを反映し熱伝導度が高い ことから, 合金化による熱電特性の高性能化が行われており, $\mathrm{Mg}_{2} \mathrm{Si}_{1-x} \mathrm{Ge}_{x}$ 系や $\mathrm{Mg}_{2} \mathrm{Si}_{1-x} \mathrm{Sn}_{x}$ 系で $Z T$ が 1 を超える高い特性が 得られている19-22). 一方で，ノンドーピングの $\mathrm{Mg}_{2} \mathrm{Si}$ に対す る熱電特性研究はそれほど多くされてはいない23).そのため, SPS 法を用い，ノンドーピング系について粉砕およびSPS 条 件による熱電性能への依存性を調べると共に電子構造計算を 行い，計算されたバンド構造を用いて熱電特性の計算を行つ た、計算結果と実験との比較により，計算結果と実験との整 合性を調べ，第一原理計算に基づく熱電特性評価の可能性の 評価を行った ${ }^{24,25)}$.

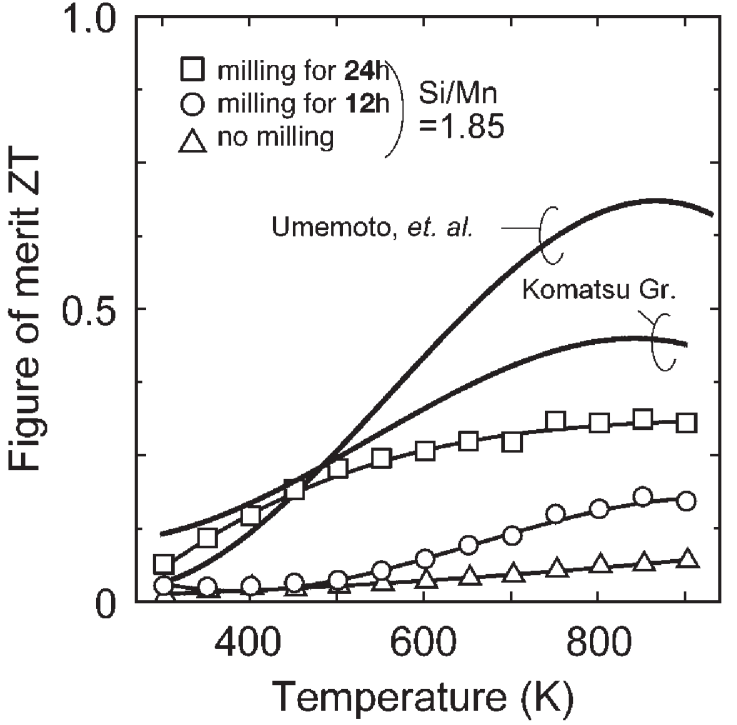

Fig.7 Dimensionless figure of merit of $\mathrm{MnSi}_{\mathrm{x}}$ as a function of temperatures.

\section{1 実験手法}

$\mathrm{Mg}_{2} \mathrm{Si}$ 試料作成の出発原料は粒径 $180 \mu \mathrm{m}$ 以下の $\mathrm{Mg}(99.9 \%)$ 粉末およびSi (99.999\%) を用いた.Siについては出発原料を 乳鉢にて $250 \mu \mathrm{m}$ 以下に粉砕後, 更にボールミル (アルミナ, $\phi=10 \mathrm{~mm})$ により $\mathrm{Ar}$ 雾囲気において 48 時間粉砕した。これ らの粉末試料を化学量論組成 $\mathrm{Mg}: \mathrm{Si}=2: 1$ に秤量・混合を行 い, Ar雾囲気で $830 \mathrm{~K}, 4$ 時間, 固相反応を行った. 固相反応 後の粉末を Milling し, 真空雾囲気のもと保持時間 30 分, 24 MPaでSPSにより焼結した. なお, Milling 時のボールサイズ および焼結温度はTable 3に示す条件にとり, 異なる作成条件 で試料を作成した。

\section{2 結果と考察}

Fig.8は各試料に対する熱電能の温度変化および小松グルー プの結果との比較を示す. また, Fig.9 は電気伝導度の温度変 化を示す.小松グループの試料は原料を溶融し, SPS $(1133 \mathrm{~K})$ 
Table 3 Fabrication condition of $\mathrm{Mg}_{2} \mathrm{Si}$ samples.

\begin{tabular}{|c|c|c|}
\hline Milling ball & $\begin{array}{c}\text { Sintering temp. } \\
(\mathrm{K})\end{array}$ & Sample name \\
\hline \multirow{2}{*}{$\begin{array}{c}\text { (Alumina) } \\
\text { (Al0mm }\end{array}$} & 973 & $\mathrm{MgSi}: 1$ \\
\cline { 2 - 3 } & 1073 & $\mathrm{MgSi}: 2$ \\
\hline \multirow{2}{*}{$\begin{array}{c}\text { (SUS) } \\
\text { (SUm }\end{array}$} & 1073 & $\mathrm{MgSi}: 3$ \\
\cline { 2 - 3 } & 1113 & $\mathrm{MgSi}: 4$ \\
\hline
\end{tabular}

* Sintering time is 1800 seconds.

*The pressure is $24 \mathrm{MPa}$.

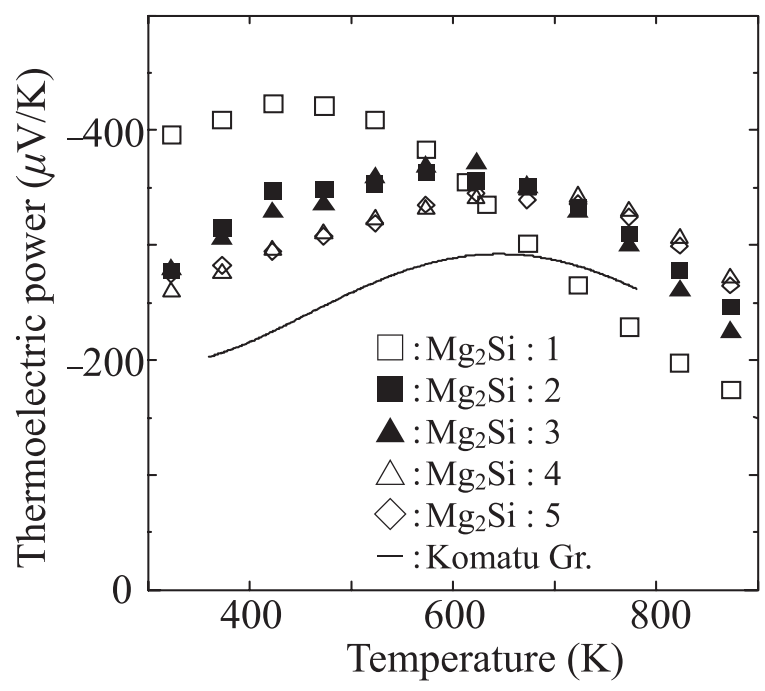

Fig.8 Thermoelectric power of $\mathrm{Mg}_{2} \mathrm{Si}$.

により作成されている ${ }^{23)}$. Fig.8において試料 \#1～5へと焼 結温度が高くなるにつれ熱電能が下がる傾向が示されている. また, 電気伝導度については逆に焼結温度の上昇と共に電気 伝導度が増大している.このことから, 熱電能および電気伝 導度に見られる違いの大きな要因はキャリアー濃度による違 いであることが示唆される.なお, 試料\#1のみ熱電能が他の 試料と大きく異なっており, 電気伝導度の温度依存性も異な ることから, 電子構造が異なっているなどミクロな構造が 違っていることが考えられる. 小松グループの結果は試料\#5 と同様の傾向と示し, 我々の焼結温度依存性に従っている.

$800 \mathrm{~K}$ 以上の温度で熱電能および電気伝導度が共に最も高 い特性を示した試料５について, Hall測定および熱伝導度測 定を行った. 室温での Hall 係数は $R_{\mathrm{H}}=1.65 \times 10^{-6} \mathrm{~m}^{3} / \mathrm{C}$ であり， キャリアー濃度は $3.79 \times 10^{18} \mathrm{~cm}^{3}$ となる。 これにより, キャリ アー移動度は $\mu=229 \mathrm{~cm}^{2} / \mathrm{Vs}$ となる. 単結晶試料では室温で キャリアー移動度 $\mu=350 \mathrm{~cm}^{2} / \mathrm{Vs}$ であり, 室温以上の温度領域 では音響フォノン散乱と electron-hole 散乱が主要なキャリ ア一散乱機構であることが報告されている ${ }^{16)}$. SPS 試料の移 動度は単結晶試料とほぼ同程度の移動度であることから, 焼

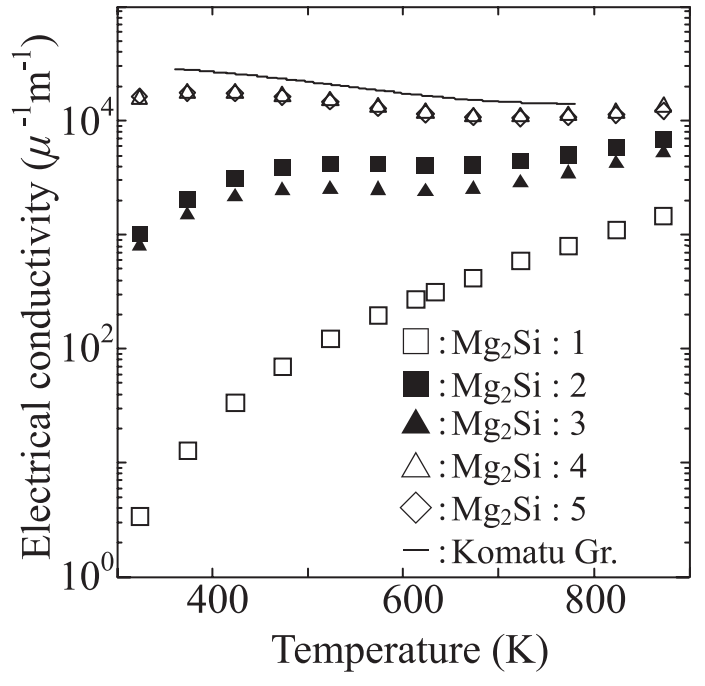

Fig.9 Electric conductivity of $\mathrm{Mg}_{2} \mathrm{Si}$.

結体の場合にも, 粒界界面での散乱よりフォノンおよびキャ リアー間散乱が主要であることが示唆される. SPS 法により 緻密な試料が作製できたため, 界面での欠陥等の生成が押さ えられ,キャリアー散乱が低減されている可能性も考えられる.

熱伝導度の測定では, 室温で熱伝導度は $\kappa=9.7 \mathrm{~W} / \mathrm{mK}$, Wiedemann-Franz則から見積もられたキャリアーの寄与は $\kappa_{\mathrm{e}}=$ $0.12 \mathrm{~W} / \mathrm{mK}$ である. 熱伝導のほとんどが格子による熱伝導に なっている.温度の上昇と共に熱伝導度はほぼ単調に減少し, $800 \mathrm{~K}$ では $4 \mathrm{~W} / \mathrm{mK}$ 程度となった. 無次元性能指数は $770 \mathrm{~K} て ゙$ 最大となり ZT $=0.23$ とノンドープ系では比較的高い值が得ら れた.

\section{3 計算による解析}

熱電能は線形化された Boltzmann 方程式および緩和時間近 似を用いて，次のように与えられる。

$$
S=\frac{k_{B}}{e} \frac{\int d \varepsilon\left(-\frac{\partial f(\varepsilon)}{\partial \varepsilon}\right) \rho(\varepsilon) v(\varepsilon)^{2} \tau(\varepsilon) \frac{\varepsilon-\mu}{k_{B} T}}{\int d \varepsilon\left(-\frac{\partial f(\varepsilon)}{\partial \varepsilon}\right) \rho(\varepsilon) v(\varepsilon)^{2} \tau(\varepsilon)}
$$

ここで, $f(\varepsilon)$ はエネルギー $\varepsilon に$ 対する Fermi 分布関数, $\rho(\varepsilon)$ は 状態密度, $v(\varepsilon)$ は速度, $\tau(\varepsilon)$ は緩和時間を表す。第一原理計 算によるバンド構造の計算結果を用いた熱電能計算では, 緩 和時間 $\tau(\varepsilon)$ 以外の量は計算されたバンド構造から得られる。 緩和時間についてはエネルギー依存性を無視した近似を行う。 この場合, 式(1)の分母, 分子で緩和時間がキャンセルするた め, 結局, 熱電能は電子構造のみにより決まる, なお, 化学 ポテンシャル $\mu$ はキャリアー数に対するバランス方程式から $T=0$ でのキャリアー濃度を与えれば全温度領域で決まる.な お, バンド構造については温度依存性およびキャリアー数依 存性は無視する.

Fig.10は $\mathrm{Mg}_{2} \mathrm{Si}$ のバンド構造計算の結果を用いて計算され た熱電能の温度依存性を示す. 小松グループの実験結果を用 


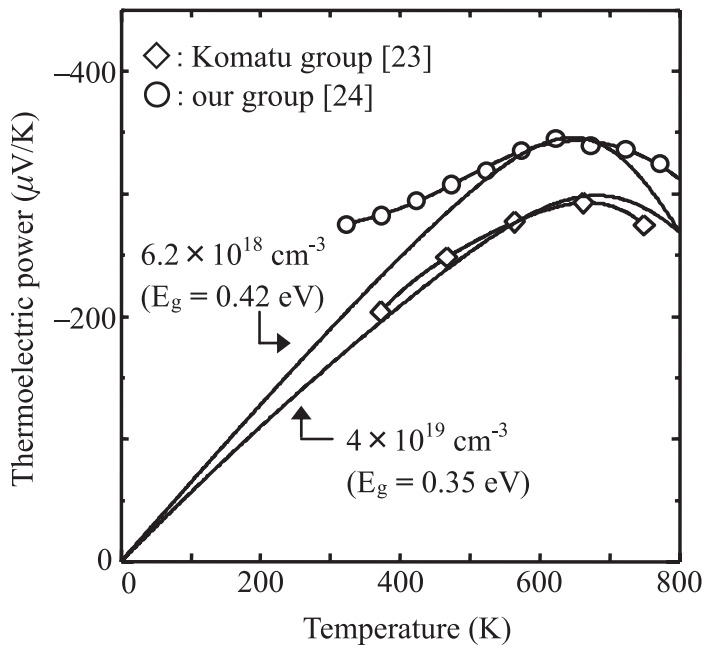

Fig.10 Calculated thermoelectric power of $\mathrm{Mg}_{2} \mathrm{Si}$ as a function of temperatures.

いた解析結果も示した. 計算において, $T=0$ でのキャリアー 濃度は実験值を再現するように決めた。 また, バンドギャッ プも計算結果を用いず実験值に合うように決めた. 密度沉関 数法では自己相互作用による過剩な斥力効果のためバンド ギャップを過小評価することが知られているためである ${ }^{26)}$. 計算結果は我々のグループおよび小松グループの実験結果を 再現している. 計算に用いたバンドギャップは $0.42 \mathrm{eV}$ ，キャ リアー濃度は $6.2 \times 10^{18} \mathrm{~cm}^{-3}$ である. バンドギャプは実験結果 より若干小さな值となった. キャリアー濃度については実験 值の 2 倍程度の值である.この計算結果と Hall測定から決ま るキャリアー濃度との違いはバンドの非方物性により理解で きる. このため, 第一原理計算に基づく計算手法は熱電能特 性を定量的に評価できることが分かった。

\section{5 ま とめ}

SPS 法を用いた高性能熱電材料開発に加え, 第一原理計算 による熱電特性評価, 更には材料探査への取り組みについて 述べた.これにより.試料の高密度化や粒界の微細化による 高性能化が可能であり, SPS 法が高性能材料開発に有効な焼 結法であることが示された．また，理論予測的な手法により 実験結果を定量的に評価可能であり, 実験と理論の融合手法 を用いた物質探査に対する可能性を示すことができた.

\section{謝 辞}

本論文は,これまでに我々のグループにおいて行われた熱 電変換材料に関する研究の一部を紹介する内容であり, 研究 に協力された古賀健治氏，櫻井俊爾氏，有田直樹氏に感謝し ます。

\section{文献}

1) ECCJ: Infrastructure Improvement Project for Rationalization of International Energy FY2003 Final Report NEDO-IC-02ED-03, 100003363, NEDO, (2003).

2) K.Matsubara and M.Matsuura: Thermoelectric Handbook Macro to Nano, Ed. Rowe, CRC Press, (2006), §52.

3) G.A.Slack: CRC Handbook of Thermoelectrics, ed. Rowe, CRC Press, (1995) 407.

4) T.Caillat, J.-P.Fleurial and A.Borshchevsky: "Preparation and thermoelectric properties of semiconducting $\mathrm{Zn}_{4} \mathrm{Sb}_{3}$ ", J. Phys. Chem. Solids, 58(1997)1119-1125.

5) H.Ozora, J.Nagai, H.Hayasi and K.Fujii: Proceedings of TEC2002, (2002) 24.

6) H.W.Mayer, I.Mikhail and K.Schudert: "Uber einige phasen der Mischungen $\mathrm{ZnSb}_{\mathrm{N}}$ und $\mathrm{CdSb}_{\mathrm{N}}$ ", J. Less-Common Metals, 59(1978)43-52.

7) G.J.Snyder, M.Christensen, E.Nishibori, T.Caillat and B.B.Iversen: "Disordered zinc in $\mathrm{Zn}_{4} \mathrm{Sb}_{3}$ with phonon-glass and electron-crystal thermoelectric properties", Nature material, 3 (2004)458-463.

8) F.Cargnoni, E.Nishibori, P.Rabiller, L.Bertini, G.J.Snyder, M.Christensen, C.Catti and B.B.Iversen: "Interstitial Zn Atoms Do the Trick in Thermoelectric Zinc Antimonide, $\mathrm{Zn}_{4} \mathrm{Sb}_{3}$ : A Combined Maximum Entropy Method X-ray Electron Density and Ab Initio Electronic Structure Study", Chem. Eur, J., 10 (2004)3861-3870.

9) T.Kumise, K.Koga, K.Akai, H.Kurisu, S.Yamamoto and M.Matsuura: "Preparation and Thermoelectric Properties of $\mathrm{Zn}$-Sb Compound Systems", Prog. and Abst. of $15^{\text {th }}$ Symp. of the MRSJ, (2004) D2-O17, 105.

10) T.Kumise, T.Koda, S.Mishiro, K.Koga, K.Akai, H.Kurisu, S.Yamamoto and M.Matsuura: "Improvement of thermoelectric properties and mechanical strength for $\mathrm{Zn}$-Sb compound system by high density", Proceedings of TEC2005, (2005)94-95.

11) M.Umemoto, Z.G.Liu, R.Omatszawa and K.Tsuchiya: "Production and Characterization of Mn-Si Thermoelectric Material", Materials Science Forum, 343-346(2000)918.

12) Komatsu group: Report on International Cooperative Research proposal Program, NEDO, (2000).

13) V.A.Korshunov, F.A.Sidorenko, P.V.Gel'd and K.N.Davydov: Fiz. Metal. Metalloved, 12(1961) 277.

14) D.C.Fredricson, S.Lee, R.Hoffmann and J.Lin: "The Nowotny Chimney Ladder Phases: Following the cpseudo Clue toward an Explanation of the 14 Electron Rule", Inorg. Chem., 43 (2004)6151-6158.

15) S.Sakurai, K.Koga, K.Akai, H.Kurisu, S.Yamamoto and M.Matsuura: "Thermoelectic Properties of Mn-Si Ceramics", Trans. MRSJ., 28(3) (2003) 801-804.

16) R.G.Morris, R.D.Redin and G.C.Danielsen: "Semiconducting Properties of $\mathrm{Mg}_{2}$ Si Single Crystals", Phys. Rev., 109(1958) 1909-1915. 
17) B.Arnaud and M.Alouani: "Electron-hole excitations in $\mathrm{Mg}_{2} \mathrm{~S}$ and $\mathrm{Mg}_{2} \mathrm{Ge}$ compounds", Phys. Rev., B64(2001)033202-1-4.

18) T.Kajikawa, K.Shida, K.Shiraishi and T.Ito: "Thermoelectric Figure of Merit of Impurity Doped and Hot-pressed Magnesium Silicide Elements", Proc. $17^{\text {th }}$ Int. Conf. on Thermoelectrics, Nagoya, Japan, ITS, (1998)362-369.

19) H.Kon, Y.Noda, Y.Furukawa, I.Nishida and K.Masumoto: "Temperature Dependence of Thermoelectric Properties of $\mathrm{Mg}_{2} \mathrm{Si}_{0.6} \mathrm{Ge}_{0.4}$ ", J. Japan Inst. Metals, 55(1991)1018-1022.

20) V.K.Zaitsev, M.I.Fedorov, I.S.Eremin and E.A.Gurieva: "Thermoelectrics on the Base of Solid Solutions of $\mathrm{Mg}_{2} \mathrm{~B}^{\mathrm{IV}}$ Compounds $\left(\mathrm{B}^{\mathrm{IV}}=\mathrm{Si}, \mathrm{Ge}, \mathrm{Sn}\right)$ ", Thermoelectric Handbook Macro to Nano, Ed. Rowe, CRC Press, (2006), \$29 and in the references.

21) V.K.Zaitsev, M.I.Fedorov, E.A.Gurieva, I.S.Eremin, P.P.Konstantinov, A.Y.Samunin and M.V.Vedernikov: "Highly effective $\mathrm{Mg}_{2} \mathrm{Si}_{1-\mathrm{x}} \mathrm{Sn}_{\mathrm{x}}$ thermoelectrics", Phys. Rev., B74(2006)
045207-1-5.

22) Y.Isoda, T.nagai, H.Fujiu, Y.Imai and Y.Shinohara: "Thermoelectric Properties of Sb-doped $\mathrm{Mg}_{2} \mathrm{Si}_{0.5} \mathrm{Sn}_{0.5}$ ", Proc. of $24^{\text {th }}$ Int. Conf. on Thermoelectrics, Vienna, Austria, ITS, (2006)406-410.

23) Komatsu group: Report on International Cooperative Research proposal Program, NEDO, (2001) in Japanese.

24) N.Arita, S.Sakurai, H.Kurisu, S.Yamamoto and M.Matsuura: "Thermoelectric Properties of $\mathrm{Mg}_{2} \mathrm{Si}$ Processed by Spark Plasma Sintering Method", Trans. MRSJ, 28(3)(2003)797-800.

25) N.Arita, K.Koga, K.Akai, H.Kurisu, S.Yamamoto and M.Matsuura: "Thermoelectric Properties and Electronic Structure of $\mathrm{Mg}_{2} \mathrm{Si}$ System", Trans. MRSJ, 29(6) (2004)25552558.

26) J.P.Perdew and A.Zunger: "Self-interaction correction to density-functional approximation for many-electron system", Phys. Rev., B23(1981)5048-5079. 